\title{
THE ETHNIC POLICY OF THE RULING GOVERNMENTS IN IRAN UNTIL THE END OF THE PAHLAVI DYNASTY
}

\author{
Mohsen Nashir Liqvan ${ }^{1}$ \\ Asghar Partovi ${ }^{2}$ \\ Bahman keshavarz ${ }^{3}$ \\ Hasan Eaivazzadeh ${ }^{4}$
}

\begin{abstract}
Many of the world's political analysts who have contributed to the theory and study of contradictions and crises, they agree that today, unlike the past, the main sources of conflicts and crises on the global level are not the economy. But the main source of challenges and contradictions is ethnic, cultural conflict and many of the countries that were born in the past with a painful process of nation-building. Now they have been questioned as a national unit, and the moves of ethnicity and separatism have absorbed them.

Purpose: Attention to traditional and ethnic structures and the entry and presence of the government in the field of policy and political management of tribal diversity in Iran, which has been followed up by regulating ethnicity,
\end{abstract} state, and supervision of the movements of the ethnic groups (Jenkins, Richard, 1997).

Method: The practices and methods and rules have been examined by governments and regulating their interactions and relations with their relatives and their management and policy. As a result, Iran is described as a tumultuous society in which various ethnic and tribal groups have been in constant conflict with the state and with each other.

Keyword: Iran, Pahlavi Hierarchy, Ethnic Policy, Management

\section{Introduction1.}

\footnotetext{
${ }^{1} \mathrm{Ph} . \mathrm{D}$. Student of political science, Faculty of Humanities and Social Sciences, Zanjan Branch, Islamic Azad University, Zanjan, Iran.

${ }^{2} \mathrm{PhD}$, Faculty Member of political science Department, Azad University, Zanjan, Iran.

${ }^{3} \mathrm{PhD}$, Faculty Member of political science Department, Azad University, Zanjan, Iran.

${ }^{4} \mathrm{PhD}$, Faculty Member of political science Department, Azad University, Zanjan, Iran.
} 
If we look at the history of the literature of political sociology, we will find that since 1960 in the literature and works of social and political scientists, the theme of ethnicity and ethnic solidarity as a peripheral issue is discussed in the mainstream of the process of development or nationbuilding. But since 1960, along with the revival of ethnic identities and the growth of conflicts that were more based on ethnicity, in all parts of the world, scientists focused in this area (Ahmadi, 1926). In fact, this ethnic rebirth from all over the world from developed industrialized countries to the developing and backward developing country's scientists have made this point which seeks out the common structures that lead to emerging of ethnicity and the rise of it as a basis for group identity and solidarity (Ashraf, Ahmad 2005). Both categories of ethnic diversity and ethnicity have long been an undeniable fact in Iran. But in explaining the reasons for the emerge of diversity in Iran, geographically, has described Iran's plateau as a triangle. Zagros and Alborz are two sides and the base of this vast desert in the east of Iran, Azerbaijan, Khuzestan and hot Sistan and Baluchestan, Cold Armenia and Kurdistan, humid Mazandaran and Gilan are located outside of the triangle (Brown. D, 1995). This different geography has created a special ethnic diversity in Iran. In addition, migrate different ethnic groups to this plateau has increased the depth and breadth of depth and diversity. Though in spite of the racial, religious and linguistic differences, Iranians have lived in peace for thousands of years together (Ahmadi, 2004). But Iran's history has been fraught with ethnic conflicts, some historians believe that the role of tribal, ethnic, sectarian and religious rivalries in the emergence and collapse of most of the local and patriotic governments of Iran undeniably (Eftekhari, Asghar 2004) . Regardless of the correctness or inaccuracy of this theory, history of Iran has been a source of tribal, ethnic, sectarian and religious conflicts.( Ethnic disparity and national security, the Center for Strategic Review of the Expediency Council), although the cultural presence of people and nations has always led to the birth and cultural dynamics of the country throughout Iranian history; but at the same time, due to some important political, social and economic variables in the internal and 
external areas, the conditions and situation are provided and appeared for problems and harm that take place in the ethnic areas Security (Brown, Micheal E, 1993) .

One of these important and influential variables on the ethnic communities of the country is the approaches, the practices, and attitudes of governments in regulating their interactions and relations with their relatives and management are the mechanisms and rules that govern these interactions.

The importance and place of this variable in explaining and analyzing ethnic issues in Iran is so much that many scholars and researchers find out the relations between the state and the relatives and the type and way of these relationships are the main factors of strengthening and consolidation of national identity and national solidarity or vice versa weakening (Davis, H.B, 1982). In countries like Iran, faced with the phenomenon of ethnic and cultural diversity, the type and way of these relationships between the government and the relatives are determined by designing and defining the specific legal and administrative procedures that their collections are called politics and ethnic
196

management. A review of the political and social history and the developments that have taken place in the country suggests it, that the relations between people and governments, especially in the history of contemporary Iran, have faced many fluctuations and ups and downs. During this time, the perceptions and views of governments have been influenced by various issues, including the social base and their nature on ethnic groups, different policies, and management patterns. Totally, the government's approach to this topic has been less interactive.

The dilemmas of this kind of management patterns in the community in some cases create a gap and identity breaks between ethnic identities and national identities, unbalanced distribution of opportunities and economic privileges, emerge a sense of relative deprivation among parts of the masses of people, the spread of poverty and unemployment, and various political and social crises in ethnic areas. Relations between people and the political system in contemporary Iran's history have had many problems with coexistence and interaction with the exception of the Islāmic Revolution and the imposed war that the will of 
coexistence, the engagement and the allround engagement of the people, especially the relatives in various political and social spheres, and the administration of the battlefields were realized in its highest form; in other sections and domains these interactions are influenced by various internal factors and the international has always been in trouble and when it was felt, the government is weakened and the political system is unable to keep up the presence and exercise of sovereignty throughout the country; there have been small and big ups and downs in the territory of the ethnic groups which resulted in endangering territorial integrity and national sovereignty and weakening the consensus of identity and national unity and political instability (Afshar, Mahmoud,1926).

According to traditional and ethnic structures and the entry and presence of the government in the field of policy and political management of ethnic diversity in Iran for regulating ethnicity, government and monitoring the movements of ethnic groups; it has a long history in Iran's political history. With the difference, first, that in each period was implemented different tools, methods, approaches, goals. And secondly, historically, before the emergence and formation of a modern state in Iran before 1300 AD, in its current sense, it has not yet entered political and social literature in Iran.

Even the concepts of ethnicity are not fully compliant with the specific social conditions in Iran. Instead, concepts were posed such as the tribal system, tribal, kinsman, and family. Therefore, in this period, what was called "policies and programs" from the central government area was designed and implemented, under the same headings. This study examines when discussing the critique of government policies of the Pahlavi era before comes up and the words of ethnic groups or deprived areas are marginalized, should also generalize topics to ethnic domains. According to this introduction examines the ethnic policy of governments in Iran from the pre-Islamic period to the section before the Islāmic Revolution in 1979.

\section{Relationship of Governments with relatives, kinsman, and ethnic groups in Iran}

Relationships and relations between ethnic groups and ethnic groups 
by building political power and the rule in Iran can be classified around several axes: The ethnic groups and tribal groups of Iran have been in power and held the government that the most prominent examples of this are Afshar, Zand, and Qajar, ethnic groups.

2. Tribes and kinsman were partners and supporter of the government. Such as the Qizilbash tribe during the Safavid dynasty.

3. Kinsman and ethnic groups have been contenders and rivals of the government, like the Qajar bloody struggle Fath Ali Khan Mohammad Hassan,

Sometimes due to the pressure and tyranny that came to the ethnic groups, they have been in conflict with the government.

4. Sometimes they were at war with the government because of the pressure and tyranny that they inflicted on ethnic groups and ethnic groupsThe study of the interaction and relations of the ethnic groups with the political power and national governments of Iran is more important from the Qajar dynasty because the streaks of crisis and transformation in the life of the ethnic groups have begun from the beginning of the reign of Qajar. In other words, it was from that time, and interventions of foreign colonialism in the country have come from power to action and gradually spread throughout the lives of people and Iran was kneeling against the military and technological power of Europeans. The clearest manifestation of this was the defeat of the military against the tsarist government and the loss of a part of the territory of the country. In fact, Relations between Europe and Iran began two centuries earlier, namely the sixteenth century AD.

But in the late eighteenth and early nineteenth centuries the nature of relations between Europe and Iran changed, and our country was initially under the pressure of powerful European governments. The nature and quality of these military pressures differed from what Iran had ever experienced from the Uzbeks and the Ottomans. The problems that these pressures have faced in our country, it was not based on the military attacks of the nomads of Central Asia and even the Ottoman Empire. Therefore, the effects of these pressures were directly and indirectly passed on all segments of the population such as the ethnic groups. 


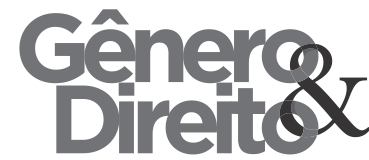

"Troubsk"

writes

in justifying this office:

Since the beginning of the period of intense colonial activity of the European governments in Iran, influenced by factors, the feudal system of patriarchal ethnic groups has undergone many changes. These transformations emerge not only in the foundations of the economic and social fabric of the ethnic groups, but also in their longstanding relationships with the central government and their social and political significance, but also in their longstanding relationships with the central government and were appeared their social and political matters. For the first time, the tribal issue goes beyond the purely internal issue of the Iranian government, and issues are rivaling foreign governments, and in this way (in this area and territory) it helps the separatist attempts of feudal leaders and scholars. European enthusiasts faced a real feudal dispersion behind the government of the Iranian unit. The nomadic tribes of Qashqai,

Bakhtiari, Shahsun and Muluk al-

Tawayev were semi-independent members of Mohamra, Mako and Poshtkouh, The Khanhans of Qucha $\mathrm{n}$ and Bojnurd and the commanders
Periódico do Núcleo de Estudos e Pesquisas sobre Gênero e Direito

Centro de Ciências Jurídicas - Universidade Federal da Paraíba

V. 8 - $\mathrm{N}^{\circ} 01$ - Ano 2019

199

of Balochistan represented it and in some of them the seeds of independent statehood were also apparent (Troubsky, 1354) which is why this research is being tried. The focus of the survey of the Qajar period is focused on analyzing and analyzing the relations between ethnic groups and governments and the policies that were applied to them during this relatively long period.

\section{Relations between ethnic groups and the government in Iran}

We will say that the ethnic groups of isolated groups are primitive and unmanageable; on the contrary, they have created large powerful states and may create by governments. History shows how these two institutions have been in constant communication a relationship that has not necessarily been conflicting. In addition to the issue of ethnic groups as states creators, there was a continuous relationship between governments and states, ethnic groups and governments within the framework of a single system of people, and keeping each other up. The 19th and 20th-century tribe communities were associated with a more new organized society called the 
government and were not in isolation mode.

\section{The various aspects of the} relationship between government and the state

Relations between the state and the state in our country have always had different aspects. Including that:

1. The

government

acknowledged opinion chief

executives of ethnic groups

2. The chiefs of the ethnic groups were in their influential areas the appointed representatives on the part of the government or appointed as local governors.

3. ELLs are financially taxed by collecting, backed the government, and the main suppliers of Iranian troops were.

4. As the government creator

5. In some cases, governments create self-governments to meet specific goals through them. Governments create selfgovernments to make specific goals through them, and especially between rival governments and rivals of power. At least in the recent centuries, the fact is that there is no
200

any tribe completely out of the government's influence. In fact, the need to pay attention to the role of the tribe in building a government in the Middle East is that governments have played a role in creating the tribe, as well as their destruction. Shahsun tribes in Azerbaijan and Khamseh in southern Iran are two obvious examples in this regard. King Abbas created Safavid Shahsun as a special and loyal, devoted to his own person and the Safavid dynasty. Government intervention in the formation and development of the tribe has other examples in Iranian history.

6. Basic Characteristics of Iranian Tribes

The historical experience of Iran shows that the tribe is not formed on the basis of kinship relations in Iran and sociopolitical considerations have played a more important role in their formation. Economically, the tribe has a hierarchical and politically organized, and focused social organization. Iranian civilizations are dispersed, Noncoherent, and involved in many internal competitions. 
These groups were not isolated societies, and their relationship with the various governments has not always been hostile and overwhelming. Many ethnic groups formed strong governments and they created the ethnic groups for political reasons. In the greatest of stages of Iran's history, the chiefs of the ethnic groups were kings' representatives and it's better to say that their relationships are historically more based on mutual support. It is important to note that, in spite of these facts, some ethnic scholars do not have the necessary historical sensitivity to understand the complex relationships between the state and the tribe. The result of this insensitivity is that the tribe is introduced as the owner of certain cultures and identities. Specific tribal and ethnic identities are actually constructed by the minds of Western social sciences scholars.

Cultural and political dispersion in the ethnic groups Generally linguistic, religious, and political divisions have been an important factor in creating a sense of distinction between different Islāmic groups in Iran. Iran's tribe, apart from the structural differences, differed in terms of language
201

and dialect and religion, as well as the degree of dependence on the central government. In the following of the rivalries and conflicts between different countries of Iran, intra-tribal tensions also played an important role. Frederick Barrett refers to this fact during the study of the southern Islāmic groups, that a small discrepancy easily leads to separate part of the tribe, and creates a new unit or joins to another camp. Attendance such rivalries among the tribe has enabled the central government to suppress any disobedience or rebellion among them through their internal and external conflicts, Lambton writes that the Qajars were able to stay in power for a long time, because the IL khans (heads of confederations or large groups) did not have the fundamental power to unite against it. The concentration and a hierarchy existence of socioeconomic in tribal groups undermine the fundamentals of the theory that ethnic groups are decentralized and egalitarian societies. Organized groups are not specific communities based on kinship relations and cultural cohesion of particular identities. Income on expanding racial and ethnic diversity in Iran Historical studies of the tribal life 
and the way ethnic and racial groups attacked Iran is indicative of the growth and diversity of ethnic groups within the Iranian plateau.

Undoubtedly, the first and most important issue that has an impact on expanding this ethnic and racial diversity and the spread of this kind of livelihood is the question of geography and natural factors Stalin, J.V, 1952). History shows that Iranian society was generally influenced by two types of geographic system; one geographical environment outside the Iranian plateau, and another geographical system of Iran's plateau. These two systems undoubtedly played a major role create ethnic groups and tribal lives and the spread of ethnic and racial diversity. In the geographical environment of Iran's plateau, there are also deserts and desert lands, cold and rugged mountainous areas, as well as plains, gardens and vineyards and fertile lands and severe climate variation, has led to the formation and diversification of the type of livelihood and lifestyle produced and hence, from ancient times has been considered as the center of the civilization of the old world.
This strange climatic difference between the two prominent historians and names of Richard. N. Fry and Ramon Crimson were so impressed that they called the Wonder Land. It is a natural system and geographical environment for the creation and continuation of a kind of cultural diversity and a variety of life and livelihoods and this has led to forming cultural and economic gaps in the context of the social life of the people living in this land. So that in no nation, it cannot be found that sweetish and diverse jokes like the jokes of the different inhabitants of urban and rural areas as well as various ethnic groups and groups of Iran are made for each other. These jokes are due to cultural, social, economic and natural conflicts and geographic factors and their effects. The Ethnic Politics of the states Governing Iran before Islam Iranian Aryanians came to Iran when they came to find people who were ugly and inferior in terms of race and habits and religious ethics (Ellis, Cashmore, 1982). The behavior of the Arianites with these indigenous people, such as the dominant behavior has been defeated, especially since the Arians considered them to 
be lower than themselves. So, at first they did not have any kind of right for them, but they constantly fought with them and killed everywhere they found them. But later, when the Native's danger was overthrown for the Arians and Arians handed over to the laborious work, such as farming and education, and serving their families. The indigenous people were living with the support of the masters. From this time, the Arabs began to integrate with the natives. The Arians did not come to Iran to invade. They wanted to be established in this country, and with this aim, they should abstract their land from indigenous people, so they arrived anywhere to reach this goal. After the war with the indigenous people, they built a castle. Inside the castle they were divided into two parts; they devoted a part to the settlement of the family and the other part of the cattleman. During this period, the form of the rule was Molukottavayef. It consisted of a few families and their house was a village which they called it "Veys".It was composed of several ethnic groups and the place where that block was called Gao at that time.There were some ethnic groups of
203

people and their villages were called Velayat or Deh-e Veys.

\section{Material period}

The materialists were the Aryan people who founded the Median monarchy at the beginning of the 7 th century AD. It's not clear, when did these people come to Iran in Azerbaijan and Kurdistan today. The strong suspicion is that they are in the tenth century BC. Khashayar Shah (Xšaya-ṛ̌s̄ā) the fourth king of Achaemenid in 414 B.Cwas preparing a war with Greece. As Greek historians wrote, forty-six species of people from different races and nations participated in this war. Their troops consisted of Persians, Gorgan, Partisans, Saka. These troops were annexed by the people of Asour, Saudi Arabia, India, Lydia, Habash and other countries of Iran. The commanders of the camps were all Persian and the Shah was moving along with the whole Achaemenid family.

Iran

Achaemenid can

be considered the largest state that was formed by then and 49 people of different ethnic backgrounds lived in different countries with different religions, languages, habits, and morals. 
Iranians from each country were free to live up to their religious beliefs. The religion of the Achaemenid kings and the Iranian people was not imposed on them at all. Habits and ethics and languages of the nations were protected and beside each country were free to keep national institutions and the dynasty of its clergy and emirs. But in exchange for these passages, all the inhabitants should consider themselves servants of the king.Pay taxes and pay the troops at the time of the war and send to the places where the court appointed. Therefore, the obedience of the states was a result of Shah's laws and orders, which unites the countries of Iran. To keep up this unity, Darius the Great gave an organization to the countries. But one should not think that the powers of the Achaemenid kings in the East and West were the same because the flow of history in the East and the West was not synonymous. In the West, they were accustomed to the centrality of the Semitic person administration, while in the eastern Aryan aristocracy and their organization was five degrees.

\section{Army}

\section{4}

Apart from the 1000 people who are to be armed and ready to serve as an eternal unit. And with the exception of provincial Reconciliation, the rest were guerrillas when required; people were taken in the center and the provinces. These uneducated people gathered in different languages and habits and did not have a spiritual relationship.

\section{Religion}

The Achaemenid kings did not have religious fanaticism, and so they cast each nation into their own beliefs. They did not care about it the religious practices of other nations were brought to their countries. It is obvious that this behavior of the Achaemenid kings was to a certain extent political and to attract the hearts.

\section{Categories}

What can be deduced from the writings of Greek historians and other things that are the first floor was composed of nobles or old families. Because there was no evidence that the clerics had any influence in this period. Among the aristocracy, six 
material families were especially concerned. The leaders of the six families of Persia were entitled to enter the king without permission, the embassy, Sardari, and the state are often assigned to the heads of these families or their members and then to the families of the material.

\section{Parthia}

It is certain that the imperfect information that has come to us, the Parthian Empire was not a super-state, but Iran was then divided into several smaller states, such as Armenia, Mades, Pars, Khuzestan, Isfahan, Ray, Kerman, Yazd and etc.

These countries had autonomy in internal affairs, the religion and habits and the dynasty of their kings were reserved (The kings of these countries were mostly Parthians).

Their submission of the great king of the kingdom is thus clear when of the election of the great king in the Consultative Assembly, and during the war, they were preparing a troop and sent to a place designated by the central government. In the places where the king was not local, he was appointed by the center of the government. In the
205

center of the Parthia empires, as it was deduced, there was no absolute rule because it was a consultative assembly where important matters were resolved and concluded. This House consisted of the Parthian princes who grew up or were headed by first-degree families. Families and ethnic groups had more authority, and the local kings were, in fact, the former Utopets village.

\section{Foreign Religions}

Regarding the foreign religions, the Parthian kings applied the same notion of neglect as the Aryan qualities and religious wars were not seen in this period.

Particularly the Parthians have been generous and kind in the nation of the Jews; they supported them against the Romans. In the Christian and other religions, the paratroopers were viewed with disbelief, and the tolerance was so much that it was not prevented from infiltration of the secularism of Iran. They only wrote about the Vologases I that he was a fanatic in view of publishing sects abroad around Iran and did not go to the Jews, but wanted to join the party cavalry with the 
help of the Romans in the Palestinian war.

\section{The second Parthian Period}

Ardeshir to agree with the people collect the Avesta .Promoting the Moons and turning on the firecrackers and Zoroaster's religion became the official religion of Iran and the head of the clergy, who was dubbed "Master of Mobid."promoted to one of the most influential government officials. Ardeshir to advance his own intentions, he used hatred of people liberate the kings and local rulers during of the Parthians and the sharp dissatisfaction with the Magi during that period. The explanation that the monarchs and the princes of Ashkani were persecuted had and cruelly. Many of them were killed by some Parthian princes who fled to Mesopotamia and India and Afghanistan. Only a handful of little people remained in a small place due to the strength of the situation and Ardeshir appealed to them. The summary of Ardeshir's work in the interior affair is this:

1. Creating the centrality and transformation of kings and local
206

authorities into the nobility and the court titles and different titles

2. Collect Avesta

3. Formalizing the Zoroastrianism and interfering with the Magi in the pursuit of the apostates and opening the wills of the dead and dividing the wills

4. Dividing people into classes and grading the office workers

5. Resurrecting the Immortal Courtship of Darius I Discounts on punishments and forbidding the hand cutting

\section{Cultural Unification in} Contemporary Iran

The cultural unification in contemporary Iran is a term in the sense that there is a trend in Iran that has the same culture of Iranians. According to its believers, during the reign of Pahlavi, especially during the Reza Shah era, this policy was pursued vigorously and continued until today.

Opponents of this view claim that nations like Iran, Egypt and Greece are ancient nations that often have the characteristics of the nation in the modern sense and if we define the Iranian national identity based on 
elements such as language, religion, history, and culture none of these elements are constructed and developed by the modern state.

\section{Historical and intellectual backgrounds}

The feeling of national unity and the sense of solidarity with the Persian language and literature in premodern and pre-Western style nationalism has always been present in Iran. Despite that, many Persian speakers of their mother tongue were not Persian, the Persian language and literature were based on nationality Peters, J, 1964). The Persian language of Dari which continues the Middle Persian language or the Sassanid Pahlavi (official Sassanian language) from the era of the Samanids and the Safari, the common Persian language is used in the widest range of languages from the Balkans to India and Central Asia as a cultural and civic language official and common after the reign of the Turks of Seljuk and Ghaznavi. The Persian language is expanding on its territory, however the vast pre-Islamic Iran, there were various languages the most prominent of which was the Persian
(Pahlavi) the official Sassanian language in Iran. After Islam advente, the Arabic language is spreading in parts of Iran, especially Khorasan and Azerbaijan, but over time, this group is resolved among indigenous peoples, and only Iranianspeaking parts of Iraq and Khuzestan are spoken. After the collapse of the Samanid regime, the Turkish language gradually takes the place of the Khwarizma and Sogdian languages in the Transoxiana, and in the western part of Iran, a large part of Arran, Sharvan, and Azerbaijan are gradually abandoned. However, throughout this period, except for the 200 years after the Arab invasion, the Persian language of Dari has always have been used as the only official language and common cultural language of Iran duringtheSafavids, Samanids, Ghaznavi ds, Seljukis, Atabakans, Shrvnshahans, Kharazmshchians, Ilkhanis and Turkme is (Qara Qoyunlu, Aq Qoyunlu) and the Safavids, the Afsharians, the Zand and the Qajars.

At the time of the constitutional revolution and the later laws, the Persian language was accepted as the official language of the country (Carr, E.H. 1917). However, in Iran, linguistic 
diversity has always existed and as well as Persian language and other Iranian languages after Islam, the Turkish language was also used in Azerbaijan and in Arabic. Although the majority of Iranians follows Islam religion but religious diversity also exists and various branches of Islam, Zoroastrians, Jews, and Christians have their followers.

\section{The ethnic and linguistic structure}

\section{of Iran before the twentieth century}

The land of Iran as today has a linguistic diversity speaking in Persian on the central plateau of the urban population. The villagers spoke to Persian, Bakhtiari, Lori or Armenian, ethnic groups to Bakhtiari, Qashqai, Baluchi, Arabic or Mamassani. In the provinces of the Caspian Sea villagers used to go to Gilaki, Taleshi or Mazandaran the townsmen to Persian and Azeri Turks; tribesmen spoke to Kurdish or Turkish (Entessar, Nader, 1992) .The inhabitants of Azerbaijan generally spoke to Azeri, but in some areas inhabited by Tat and there were also Armenians and the nomads of Kurd, Shahsun, Turkmen, Afshar, and Qaradaghi. Western provinces often consisted of the ethnic
208

groups of Kurds, Lars, and Arabs, and in some places also inhabited Afshar, Azari, Fars, Bayat, Gurani, and Asuri ethnic groups (Engles, F, 1979).

In addition, the inhabitants of many Kurdish valleys used their own Kurdish dialect, southeast provinces, including the Baluch ethnic groups, Arabs, Afghans, Afshars, Kurds, and Noshirvani.

\section{Ethnic politics in the first Pahlavi era}

Inequities, inefficiencies and political, social and ethnic crises caused by the Qajars' inability to govern the country have led to the emergence of conditions in which the various strata and groups of the country, the people, the political élite and intellectuals of those days were keen to change the situation and the coming of the regime which could set up secure and manage the crisis of the country. Ahmad Kasravi has written about the power of the Pahlavi dynasty and the coming of Reza Khan. Indeed, many centers of independent power have led to a complete lack of security and disintegration of the country; this was the 
main reason for the people's support for a dictatorship.

Be political, social and security problems at the national and international levels, emerge the crisis and insurrection in the ethnic areas of the territory of the ethnic groups and areas such as Gilan and Khorasan, the pressure of the Russian and British governments under the 1907 Treaty (Iran is on the verge of deconstruction) And the northern part of Iran was occupied by the newly established Soviet government (suffering and conquests of the Constitutional Revolution and the First World War, internal rebellions, and the summary of fatigue and the plight of nobles, clerics, merchants and workers, there were those who had waited for the emergence of charismatic leadership to end this situation (Barghoorn, F, 1926).

Although the Qajar dynasty, as described in the preceding pages, had various types of harassment and tyranny in the right of the tribe and nomadic ethnic groups of the country but with the decline of Omar Nasir al-Din Shah's star and in particular the victory of the Constitutional Revolution and it caused the defeat of the Qajar tyranny and the granting of some freedoms to the Iranian people; The masses of relatives, ethnic
209

groups were also largely liberated from the oppression and misconduct of the rulers of the state and the central government officials and a few days they could take a break. But this restrained liberty was restored by the sovereign state.

But this limited freedom that has been restored was no more than the hasty government. That happened with the coup 1921 AD, which was made up of British colonial power. With the victory of the October Revolution of Russia and the overthrow of Russian Tsarism and plunder within the borders of the vast empire of the Tzaransthe political fate of Iran was exclusively in the hands of the United Kingdom.

British colonialism required a strong and centralized government to expand its influence throughout the territory of Iran. To reach this goal, it first came through democracy and Parliamentary system and sought to impose a 1919 contract by ratifying the Constitution Revolutionary Assembly (Lijphart, A, 1977). The contract was not successful due to the resistance and struggles of the Iranian people, and the British started the coup of March 1299. 
Therefore, Reza Khan's rule

was actually the same as the 1919 contract.

\section{Cultural}

Unification

in Reza Shah's Period

The imminent danger of Gilan, the riots in Azerbaijan, the permanent wars between the ethnic groups, the Red Army presence in the north, the uprising in the Gendarmerie force, and the Kazakh factions, and the government inability to form a parliamentary party that confirms the undesirable agreement between Iran and Britain all helped create an acute political crisis in the capital. In the middle of the crisis, Colonel Reza Khan, a Forty-two-yearold officer of an anonymous military and Turk-speaking family in Mazandaran, who had passed military degrees and commanded by the Qazvinbased Brigadier, who had passed military degrees and commanded by the Qazvin-based Brigadier, The three thousand men in troop moved to Tehran. He received the support of gendarme officers and British military advisers and he entered Tehran on the third night of March. He arrested sixty men from the first regiment. He assured the king that the coup would take place to save the monarchy from the danger of the revolution and he asked that Seyed Zia becomes prime minister. In announcing form their own government the two stated that they would start the era of national revival by ending the internal disintegration, social transformation, and saving the country from occupying foreigners.

Reza Shah Royalty: 1927-1942

The reign of Reza Shah saw create a new order, to secure his absolute power, independent newspapers closed down, denied parliamentary immunity from deputies and more importantly, eliminated political parties . The revival party, which honestly supported Reza Shah ,First, he gave his place in the new Party of Iran and the party (an organizational advance to emulate a Mussolini's fascist party and Republican Party Atatürk). But even this progressive party would soon be dismantled to believe that Republican dangerous intentions were in place. But even that party is coming up soon to have been dissolved due to thinking that the republican dangerous intentions. Although Reza Shah had 
never laid out a basic plan for the modernization of the country, the acquisition of uncontested power began social reforms (Did not write a major thesis, did not make important lectures and did not make a will). But he made some changes that although was not regular, but it shows that he wanted to build an Iran that, on the one hand, was free from clerics, foreign conspiracy, tribal rebellion and ethnic differences influence, however, there is Europeanstyle educational institutions, modern women working outside the home, a new economic structure with government factories, communication networks, investment banks and chain stores. In order to make his goal of rebuilding Iran, according to the image of the west, he began to rebel, dismantle tribalism, nationalism, educational development, and state capitalism (Smith, 1993).

\section{Manage ethnic rhetoric and minorities during pre-Islamic victories}

In the periods discussed from ancient Iran until the end of Pahlavi II, in general, and in practice we have seen several ethnic management strategies:
211

1) The strategy of maintaining national solidarity through establishing family ties between tribal chiefs elites and local influences with the king and courtiers (Qajar era)

2) The strategy of curbing and suppressing the rulers and chiefs of the ethnic groups and tribesmen (Pahlavi I).

3) Modernization strategy combined with cultural contempt and economic discrimination in the ethnic areas (Pahlavi II).

The experience of Iranian history shows that in different times, varieties of policies have been applied with regard to the nature and type of political regime in the establishment of solidarity and public and national consensus. For example, the Qajar model of ethnic politics is based on the pluralistic patterns and politics of the first and second Pahlavi regimes(Pahlavi I, II) with differences in the way of applying, the policy of replicating and during the Islāmic Republic, he was inclined to the legal model of pluralism (Smith, M.G, 1969). 
18. Conclusion of the ethnic policy of governments in Iran until the end of Pahlavi II

As noted, the ethnic groups in Iran were not kinship groups, but create the Eilat and the alliance between them is basically the result of the power relations and pragmatic strategies. Iranian political groups with such a social-political foundation have not been isolated communities have no coherent cultural foundations. In fact, the concept of ethnic groups as egalitarian and decentralized groups cannot adopt the concept of large cities with fully hierarchical and centralized structures in Iran, whose political and economic power has historically been exclusively in the hands of powerful leaders and families of the ethnic groups. Iranian ethnic groups have been in constant contact with their central governments. The chiefs of the ethnic groups should generally be recognized by the kings as their leader while Iranian governments have been created by Islāmic groups. Governments in turn also created large Islāmic groups such as Shahsun in Azerbaijan, the Kurdish ethnic groups of Khorasan and the confederations of the Khums tribe in the
212

south of Iran. In addition, ethnic groups helped secure the government by collecting annual taxes from the people and providing military forces of the Iranian army. Tribes with these features and functions cannot be considered as irreducible and culturally distinct groups of other strata of the Iranian population. The extensive tribal movements, their unity and internal and external tribal rivalries and their continuous relations with governments brought ethnic groups together with other Iranians culturally. Therefore, the former Islāmic tribal groups of Iran cannot be considered as ethnic groups with such social and cultural background.

Considering organized tribal groups such as Kurds, Azeris, Baluchis, and Qashqa'is as distinct ethnic groups or ethnic identities is contrary to the historical facts. In spite that the various religious and linguistic groups in Iran have had a common historical experience and have found the same cultural and political heritage over the centuries. These cultural and political factors in various segments of the population gradually created a strong sense of belonging to the land of Iran and being Iranian. Historical insight not only 
distorts the past reality of the Iranian society but also reveals inappropriate and inadequate explanations for emerging the so-called ethnic tribal conflicts in Iran.

The inappropriate behavior of central Iranian governments in using inappropriate ways to subjugate various ethnic groups in Iran and ethnic groups, failure to pay attention to the implementation and development programs in the ethnic and border regions has caused the ethnic groups to emancipate under the yoke of central governments, other than pursuing their central interests, they did not pursue other goals in the region. They are always in a struggle for their internal security and fate and even for defending their external boundaries and always convinced of their internal independence. These issues, most of the ethnic states have become the most troublesome states in Iran, and the growth and continuity of the fragility center have been accompanied by pride and liberation and specific nerves among ethnicities and ethnic groups.

This

situation was aggravated by inappropriate policies of governments and the influence of the elements of the colonial countries, among the ethnic groups was also added to it, and some elements such as the rise of the constitutional revolution have exacerbated the crisis and created chaos in these areas. In the earlier sections, it was observed that the policies implemented in Iran with regard to the ethnic groups, nomads, and subcultures by various governments, especially since the Pahlavi I were based on ethnic identification and cultural uniformity (melting of cultures). However, applying these policies, first, has been accompanied by an interrupt, and ups and downs (Forough, Emad 2001). Secondly, the methods, tools, and modalities for implementing these policies have varied in terms of the nature of the governments and domestic demands.

This situation was aggravated by inappropriate policies of governments and the influence of the elements of the colonial countries, among the ethnic groups was also added to it, and some elements such as the rise of the constitutional revolution have exacerbated the crisis and created chaos in these areas. In the earlier sections, it was observed that the policies implemented in Iran with regard to the ethnic groups, nomads, and subcultures 
by various governments, especially since the Pahlavi I were based on ethnic identification and cultural uniformity (melting of cultures). However, applying these policies, first, has been accompanied by an interrupt, and ups and downs. Secondly, the methods, tools, and modalities for implementing these policies have varied in terms of the nature of the governments and domestic demands.

If you want to check the policies of the Pahlavi Dynasty and outline its general lines, then the features and components of the ethnic policy of this period (I and II) can be categorized and presented (this model is influenced by the experience of Turkey is the Atatürk era):

1. To create a strong concentration in the economic, political, cultural and social system.

2. The association and integration of the social, economic and cultural system of ethnic, tribal in the central system

3. Renovation and modernization of all areas of the social system

4. National unity of Iranians in the form of political, moral, psychological, emotional and social unity.
214

5. The intensification of Pan-Iranism by relying on Persian language (extreme Persian language) and Iran's identity and pre-Islamic culture (Antiquity).

6. Emphasize and rely on Aryan mythbased racism.

7. Establishing a national government and completing the nation-state process based on nationalist ideology.

8. The new army, the state bureaucracy and the use of courtiers as three tools used by Reza Khan to merge their power and government.

\section{Conclusion}

Many of the world's political analysts who have focused on theories and criticisms of contradictions and crises agree that today, unlike the past, the main sources of conflicts and crises in the world today are not the economy.

But the main source of challenges and contradictions is ethnic cultural conflict, and many countries that have been born in the past with a hard and painful process of nation-building have now become an underworld and have embraced the waves of ethnocentrism and separatism. In spite of all these views, this fact cannot be denied that contemporary Iran has seen cases of 


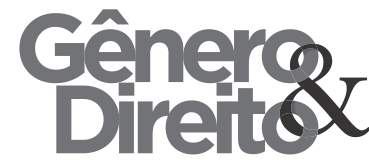

Periódico do Núcleo de Estudos e Pesquisas sobre Gênero e Direito

Centro de Ciências Jurídicas - Universidade Federal da Paraíba

V. 8 - $\mathrm{N}^{\circ} 01$ - Ano 2019

ISSN | 2179-7137 | http://periodicos.ufpb.br/ojs2/index.php/ged/index political strife in which some religiouslinguistic groups have been involved. These conflicts, which often occurred in the twentieth century, have encouraged scholars to use Western theories to study Iran's experiences. As a result, Iran is described as a struggling society in which various ethnic and tribal groups have been in constant conflict with the state and with each other. These perceptions had been used due to a lack of culture.

\section{References}

Ahmadi, Hamid 1926 Iran: Ethnicity and nationality, Tehran: Human Sciences Research and Development.

Ahmadi, Hamid 2004 Religious Ethnicity in Iran: Legend and Reality, Third Edition. Tehran: Publishing Ney.

Smith, Anthony 1993 Ethnic Resources of Nationalism, Translation Office Strategic Studies, First Issue, Spring

Ashraf, Ahmad 2005 National and Ethnic Identity Crisis in Iran, an Ahmadi. Iran (identity, nationality, and ethnicity).
215

Tehran: Institute for Human

Development and Research

Eftekhari, Asghar $2004 \quad$ Religious

Minority, Tehran: Iranian Civilization

Publication

Forough, Emad $2001 \quad$ Subcultures, Participation, and Consensus, in Culture, Politics, and Development In today's Iran, Tehran: Dahl Publishing. 546

Afshar, Mahmoud (1926), "Our Desired Idea for National Unity," Future Beginnings

Barghoorn, F. Soviet Russian Nationalism. (New York, Oxford University Press, 1950). 550

Brown. D. The State and Ethnic Politics In South East Asia (London, R.K. 1995).

Brown, Micheal E. Ethnic Conflict and International Security (New Jersey: Priceton University Press, 1993).

Carr, E.H. The Bolshevik Revolution, 1917. 1923, Vol, 1. (London, Macmillan). 


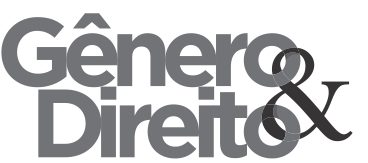

Periódico do Núcleo de Estudos e Pesquisas sobre Gênero e Direito

Centro de Ciências Jurídicas - Universidade Federal da Paraíba V. 8 - No 01 - Ano 2019

ISSN | 2179-7137 | http://periodicos.ufpb.br/ojs2/index.php/ged/index
Davis, H.B. The National Question:

Selected Writing (New York: Monthly

Review Press, 1982).

Ellis, Cashmore, Dictionary of Race and

Ethnic. (London, New York).

Engles, F. The Movement of 1847 in

K. Maru and F. Engels. Collected

Works. Vol.6 (Moscow, Progress

Publisher 1979).

Entessar,

Nader,

Kurdish Ethnonationalism.

(London: Bourder,

Lynne Rienner Publisher, 1992).

Jenkins, Richard, Rethinking Ethnicity, (London, Thausand oaks, New Delhi, 1997).

Lijphart, A. Democracy in Plural Societies, Acomparative Exploration, (New Haven, Yale University Press, 1977).

Peters, J. Stalin's Nationality Policy: an interpretation. (Pensylvania, University of Pennsylvania, 1964).

\section{6}

Smith, M.G. Institutional and Political

Conditions of Pluralism, (Berkeley:

University of California Press, 1969).

Stalin, J.V. Marxism and The National

Question in Collected Works Vol.2

(Moscow 1952 